\title{
Iron state in alpha and beta thalassaemia trait
}

\author{
JM WHITE, R RICHARDS, G JELENSKI, MARGARET BYRNE, M ALI \\ From the Department of Haematology, Corniche Hospital, Abu Dhabi, United Arab Emirates
}

SUMMARY The iron state was examined in two groups of pregnant women who were carriers of $\alpha$ and $\beta$ thalassaemia genes. In both groups the haematological expression of the disease-namely, haemoglobin and mean cell haemoglobin concentrations-was nearly identical. In patients with $\alpha$ thalassaemia the ferritin concentrations and percentage of ferritin deficiency was the same as in normal pregnant patients, whereas in those with $\beta$ thalassaemia the ferritin concentrations were usually much higher and iron deficiency four times less common. This variance appears to be explained by different degrees of extravascular or intravasular haemolysis between the two thalassaemias as assessed by the activities of serum $\alpha$ hydroxybutyrate dehydrogenase.

In 1984 Pardini et al reported that in patients with $\alpha$ thalassaemia concentrations of ferritin were similar to those of normal subjects, and were significantly lower than those associated with $\beta$ thalassaemia, but no explanation was given. ${ }^{1}$ We made a similar observation indirectly during a larger study on the haematological changes in pregnancy in over 2000 mixed ethnic patients with the thalassaemia trait $(\alpha$ and $\beta) .^{2}$ By 36 weeks' gestation patients with $\alpha$ thalassaemia showed the same incidence of iron deficiency as normal mothers (15-20\%), but in those with $\beta$ thalassaemia iron deficiency was uncommon $(4 \%)$. Moreover, the difference in routine ferritin concentrations between the two became so obvious that the association of thalassaemic indices and a "high" ferritin concentration $(>40 \mathrm{ng} / 100 \mathrm{ml})$ was almost diagnostic of $\beta$ thalassaemia, but if the concentration was normal or low $(<15 \mathrm{ng} / 100 \mathrm{ml}) \propto$ thalassaemia was suspected. We had not, however, taken into account any differences in the cellular expression betweeen the two thalassaemias - namely, haemoglobin concentrations and mean cell haemoglobin values-or made allowance for the differences in age or parity.

We therefore re-examined the problem in two selected groups of patients in which these factors, especially haematological expression, were comparable or identical. At the same time the degree of extravascular and intravascular haemolysis was assessed by measuring the concentrations of serum $\alpha$ hydroxybutyrate dehydrogenase.

Accepted for publication 7 November 1985

\section{Subjects and methods}

The subjects were peninsular Arab women (from Yemen, United Arab Emirates, and Oman) who were $\ddot{\varnothing}$ carriers of either $\alpha$ (No 42) or $\beta$ (No 23) thalassaemia. and in the 36-40 week of pregnancy. All were para II $\mathrm{C}$ $+I$ and between the ages of 20 and 25 years. They were receiving normal antenatal care with supplements of iron (100 mg three times daily) and folate. The timing of pregnancy was chosen to provide the $\frac{\mathbb{Q}}{\mathbb{Q}}$ period of highest incidence of iron deficiency. The $\underset{\Rightarrow}{\Rightarrow}$ number of pregnancies and age of each patient was 윽 included to provide some equivalence of iron loss (years of menstruation plus three pregnancies).

A control group of Arabic women over 36 weeks pregnant who had normal haemoglobin concen-? trations for the period of gestation, a normal mean 0 cell haemoglobin value, and no other clinical complications was also studied.

The routine haematological variables were measured on a Coulter model S. The performance of the 윽 laboratory was monitored monthly by the NEQAS United Kingdom quality assurance programme, and in 1983-84 the deviation index was 0.5 (good). Haemoglobin $\mathrm{A}_{2}$ concentrations were measured by poly- o dexide chromatography (normal range (SEM) $N$ $1 \cdot 8-3 \cdot 2 \%(0 \cdot 15 \%)){ }^{3}$ Serum ferritin concentrations $N$ were measured by radioimmunoassay using commercial kits (Amersham UK). Serum $\alpha$-hydroxybutyrate dehydrogenase was measured with the Boehringher $\frac{\mathscr{D}}{\mathscr{D}}$ commercial kit.

DIAGNOSIS OF $\alpha$ AND $\beta$ THALASSAEMIA

The diagnosis of $\alpha$ and $\beta$ thalassaemia was made $\stackrel{\mathbb{D}}{\mathbb{D}}$ using the criteria described previously ${ }^{2}-\frac{\overrightarrow{\mathbb{D}}}{\mathscr{Q}}$ namely, the patients were screened by discriminant 
Table 1 DNA analysis of $\alpha$ gene complex in patients with $\alpha$ thalassaemia*

\begin{tabular}{|c|c|c|c|c|c|c|c|c|c|}
\hline $\begin{array}{l}\text { No of } \\
\text { patients }\end{array}$ & $\begin{array}{l}\text { Ethnic } \\
\text { group }\end{array}$ & $\begin{array}{l}\text { Haemoglobin } \\
\mathrm{g} / \mathrm{l}\end{array}$ & $\begin{array}{l}\text { Red cell } \\
\text { count } \\
\left(\times 10^{12} / l\right)\end{array}$ & $\begin{array}{l}\text { Mean cell } \\
\text { haemoglobin } \\
\text { (pg) }\end{array}$ & $\begin{array}{l}\text { Mean cell } \\
\text { volume } \\
(p l)\end{array}$ & $\underset{(\%)}{H b A_{2}}$ & $\begin{array}{l}\text { Ferritin } \\
\mathrm{ng} / 100 \mathrm{ml}\end{array}$ & $\begin{array}{l}\text { Discriminant } \\
\text { function }\end{array}$ & Genotype \\
\hline 1 & Yemen & $\begin{array}{l}115 \\
105\end{array}$ & $\begin{array}{l}5 \cdot 14 \\
5 \cdot 01\end{array}$ & $\begin{array}{l}22 \\
22\end{array}$ & $\begin{array}{l}67 \\
64\end{array}$ & $\begin{array}{l}3 \cdot 3 \\
3 \cdot 2\end{array}$ & $\begin{array}{r}13 \cdot 2 \\
6 \cdot 0\end{array}$ & $\begin{array}{l}+1 \\
+5\end{array}$ & $\begin{array}{l}-\alpha \mid-\alpha \\
-\alpha \mid-\alpha\end{array}$ \\
\hline $\begin{array}{l}10 \\
12\end{array}$ & $\begin{array}{c}\text { United Arab } \\
\text { Emirates } \\
\text { United Arab }\end{array}$ & 108 & $4 \cdot 68$ & 22 & 72 & $3 \cdot 1$ & $18 \cdot 4$ & +9.9 & $-\alpha /-\alpha$ \\
\hline \multirow[t]{2}{*}{$\begin{array}{r}18 \\
3 \\
7\end{array}$} & $\begin{array}{l}\text { Emirates } \\
\text { Oman } \\
\text { Yemen } \\
\text { United Arab }\end{array}$ & $\begin{array}{r}107 \\
91 \\
111\end{array}$ & $\begin{array}{l}4.99 \\
4.7 \\
5.03\end{array}$ & $\begin{array}{l}21 \\
19 \\
22\end{array}$ & $\begin{array}{l}67 \\
59 \\
67\end{array}$ & $\begin{array}{l}2.9 \\
3.6 \\
2.7\end{array}$ & $\begin{array}{l}40 \cdot 8 \\
87 \cdot 0 \\
44 \cdot 5\end{array}$ & $\begin{array}{l}+5 \cdot 1 \\
+5 \cdot 4 \\
+3 \cdot 1\end{array}$ & $\begin{array}{l}-\alpha /-\alpha \\
-\alpha /-\alpha \\
-\alpha / \alpha \alpha\end{array}$ \\
\hline & Emirates & 107 & $5 \cdot 8$ & 21 & 67 & 3.8 & 56.5 & $+5 \cdot 1$ & $-\alpha / \alpha \alpha$ \\
\hline
\end{tabular}

${ }^{*}$ Data were extracted from the larger study. ${ }^{5}$ In some of these patients the ferritin and $\mathrm{Hb} \mathrm{A}_{2}$ concentrations are higher than those of the patients reported in the present study. This was probably due to technical variation.

Table 2 Haematological variables of patients with $\alpha$ or $\beta$ thalassaemia

\begin{tabular}{|c|c|c|c|c|c|c|}
\hline & \multicolumn{2}{|c|}{$\begin{array}{l}\text { Normal patients } \\
(n=50)\end{array}$} & \multicolumn{2}{|c|}{$\begin{array}{l}\text { Patients with } \alpha \text { thalassaemia } \\
(n=42)\end{array}$} & \multicolumn{2}{|c|}{$\begin{array}{l}\text { Patients with } \beta \text { thalassaemia } \\
(n=23)\end{array}$} \\
\hline & Range & Mean & Range & Mean & Range & Mean \\
\hline $\begin{array}{l}\text { Haemoglobin }(\mathrm{g} / \mathrm{l}) \\
\text { Red cell count } \times 10^{12} / 1 \\
\text { Mean cell volume }(\mathrm{fl}) \\
\text { Mean cell haemoglobin (pg) } \\
\text { Discriminant function } \\
\text { Hb } \mathrm{A}_{2}(\%)\end{array}$ & $\begin{array}{l}116-131 \\
3 \cdot 8-4 \cdot 3 \\
80-92 \\
28-32 \\
+7 \text { to }+20 \\
2 \cdot 1-2 \cdot 6\end{array}$ & $\begin{array}{l}123 \\
3 \cdot 95 \\
87 \\
30 \\
+13 \cdot 5 \\
2 \cdot 3\end{array}$ & $\begin{array}{l}84-125 \\
4 \cdot 9-6 \cdot 1 \\
63-70 \\
18-22 \\
+3 \text { to }-1 \cdot 6 \\
1 \cdot 7-2 \cdot 3\end{array}$ & $\begin{array}{l}107 \\
5 \cdot 7 \\
65 \\
21 \\
+0 \cdot 6 \\
2 \cdot 1\end{array}$ & $\begin{array}{l}87-111 \\
5 \cdot 1-6 \cdot 3 \\
62-70 \\
18-22 \\
+1 \cdot 3 \text { to }-2 \cdot 0 \\
4 \cdot 8-6 \cdot 3\end{array}$ & $\begin{array}{l}102 \\
5 \cdot 8 \\
64 \\
20 \cdot 2 \\
-1 \cdot 2 \\
5 \cdot 2\end{array}$ \\
\hline
\end{tabular}

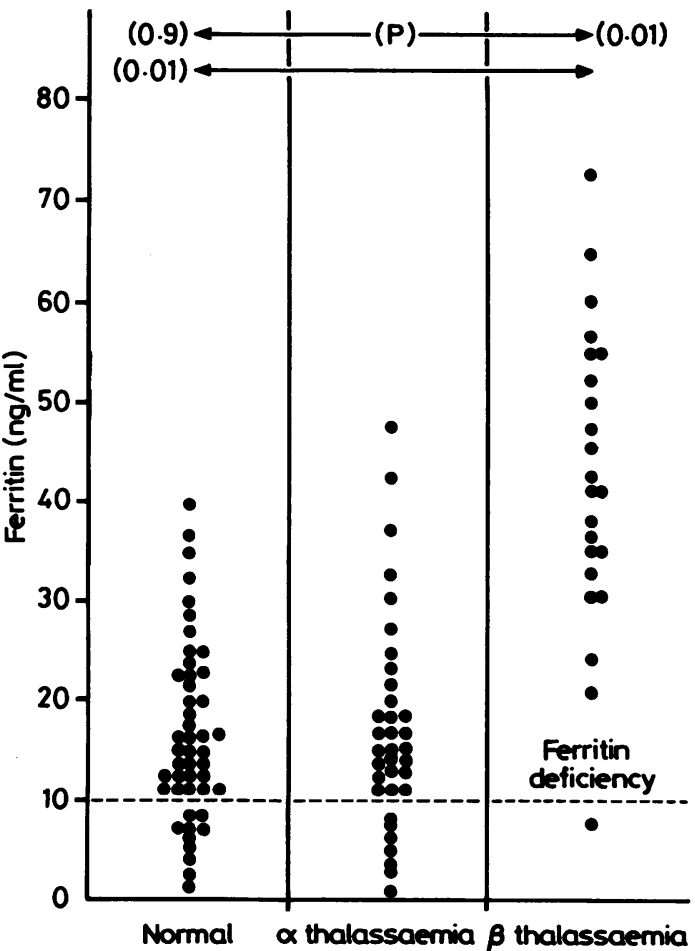

Fig. 1 Geometric means and ranges of serum ferritin concentrations in: normal non-thalassaemic patients; patients with $\alpha$ thalassaemia; and patients with $\beta$ thalassaemia. function analysis of the haematological variables using the formula: (mean cell volume - red cell count $-(5 \times$ haemoglobin concentration -3.4$)),{ }^{4}$ and if the function indicated a thalassaemic pattern they were divided into $\alpha$ and $\beta$ thalassaemia by measuring the $\mathrm{HbA}_{2}$ concentrations.

We were aware of the danger of making a diagnosis of $\alpha$ thalassaemia without biosynthetic data. The validity of this selection procedure has, however, been supported by DNA analysis of the $\alpha$ globin gene complex of seven patients with mean cell haemoglobin values of between 18 and $25 \mathrm{pg}$, selected by discriminant function analysis. ${ }^{5}$ Five of these patients werè homozygous for the 3.7 deletion and two were heterozygous (Table 1). Once the patient was diagnosed as a carrier of thalassaemia the serum ferritin concentration and $\alpha$ hydroxybutyrate dehydrogenase activity were measured on fresh repeat samples by an independent observer.

\section{Results}

Table 2 gives the range and the geometric means of the haematological variables of the two groups of patients studied compared with those of normal patients. There was little difference in the haematological expression of the thalassaemias with the exception of the mean cell haemoglobin value, which although marginally lower in the $\beta$ thalassaemia group, was still not significant. 


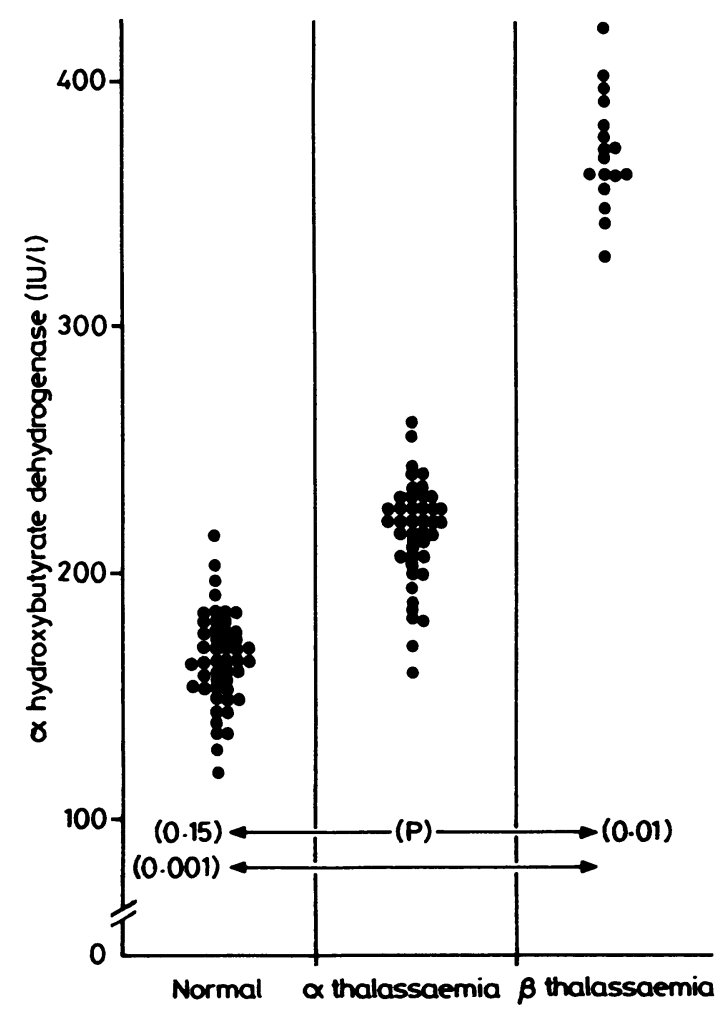

Fig. 2 Geometric means and ranges of serum hydroxybutyrate dehydrogenase $(\alpha-H B D)$ concentrations in: normal control patients; patients with $\alpha$ thalassaemia; and patients with $\beta$ thalassaemia.

Fig. 1 shows the geometric means and ranges of the serum ferritin concentration associated with the two groups of patients with thalassaemia and the normal group. There was no difference between the mean (SEM) concentration associated with $\beta$ thalassaemia $(14 \cdot 1(3 \cdot 8) \mathrm{ng} / \mathrm{ml})$ and normal $(13 \cdot 6(3 \cdot 2) \mathrm{ng} / \mathrm{ml})$, but the mean value associated with the $\beta$ thalassaemia group was much higher $(42.8(6.4) \mathrm{ng} / \mathrm{ml})$. In addition, whereas the incidence of iron deficiency ferritin $(<10 \mathrm{ng} / \mathrm{ml})$ in the $\alpha$ thalassaemia group $(16 \%)$ was roughly the same as that found in the normal pregnant group (14\%), it was only $3 \%$ in the $\beta$ thalassaemia group.

\section{SERUM HYDROXYBUTYRATE DEHYDROGENASE ACTIVITIES}

Fig. 2 shows the activites of serum $\alpha$ hydroxybutyrate dehydrogenase. The mean (SEM) value for normal controls was 176 (15) IU/1; for the $\alpha$ thalassaemia group 221 (36) IU/l; and for the $\beta$ thalassaemia group 363 (52) IU/l. The significance of difference between

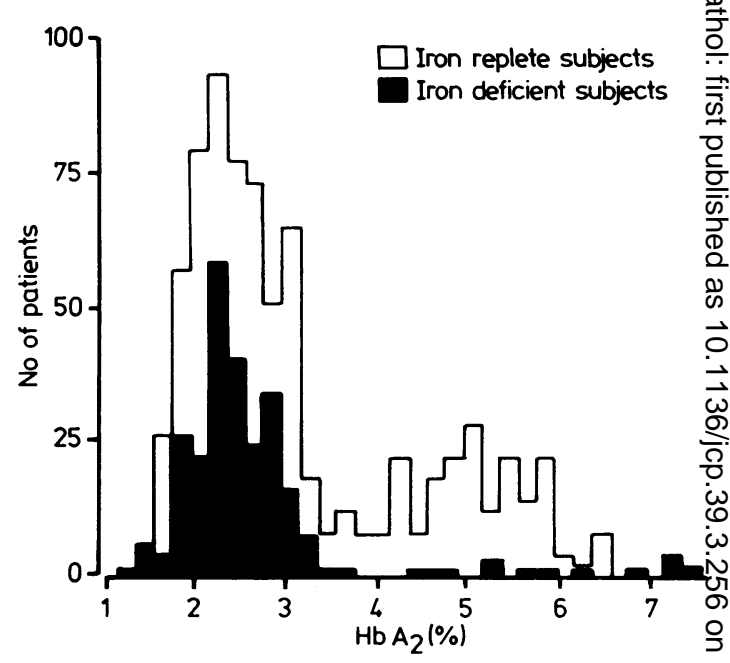

Fig. 3 Comparison between development of iron deficiency in 738 patients diagnosed as having $\alpha$ and $\beta$ thalassaemia during gestation. Unshaded curve indicates patients who were iron replete at 20 weeks and shaded area indicates those who were found to be iron deficient at $>36$ weeks. (The relative incidence of ferritin deficiency between $\alpha$ and $\beta$ is 4:1.) This figure also shows that the development of iron deficiency has litt'e if any effect on haemoglobin $A_{2}$ concentrations. If this were the case there would be a sharp left shift in the haemoglobin $A_{2}$ distribution of both $\alpha$ and $\beta$ thalassaemic patients.

patients with $\alpha$ thalassaemia and normal patients was $0 \cdot 15$, but between those with $\beta$ thalassaemia and normal patients 0.001 , and between those with $\beta$ thalassaemia and $\alpha$ thalassaemia 0.01 .

\section{Discussion}

These data confirm early findings ${ }^{2}$ that there is a $\delta$ noticeable difference in ferritin concentrations, and $₹$ presumably iron state, between carriers of $\alpha$ thal-을 assaemia and $\beta$ thalassaemia and support the findings $D$ of Pardini et al. ${ }^{1}$ The problem is simply illustrated in Fig. 3, which is taken from data from our earlier study. ${ }^{2}$ This compares the number of patients diag-o nosed as having $\alpha$ or $\beta$ thalassaemia in early preg- $N$ nancy, at which stage they had normal ferritin concentrations, with the number of those who subsequently became deficient in iron during the course

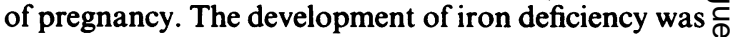
largely confined to the $\alpha$ thalassaemia group,

To determine the cause for this variance we 0 attempted in this present study to eliminate possible ${ }^{\circ}$ and obvious factors-namely, gestational variation, $\stackrel{\mathbb{D}}{\Omega}$ ethnic variation, and differences in cellular expression $\overrightarrow{\mathbb{D}}$ between the thalassaemias. With regard to the 
difference in cellular expression, although our groups were comparable, they were not exactly the same as it was difficult to find large numbers of patients with $\alpha$ thalassaemia with mean cell haemoglobin values of $18-22 \mathrm{pg}$. Nevertheless, although accepting that $\beta$ thalassaemia is marginally more severe than $\alpha$ thalassaemia, the difference is not likely to explain the noticeable difference in the ferritin concentrations. We suggest, therefore, that the difference in iron state reflects the different degrees of dyserythropoiesis or intravascular haemolysis. We are aware that the $\alpha$ hydroxybutyrate dehydrogenase activity is only a guide to intravascular haemolysis and suggest that the study should be repeated using a more sensitive marker. It is, however, a simple and readily available test and indicates that alterations in the activities of $\alpha$ hydroxybutyrate dehydrogenase may in individual patients be of value in monitoring changes in the disease.

Finally, the common, or rather "normal," incidence of iron deficiency in women with $\alpha$ thalassaemia might result in confusion as to the correct diagnosis. Alternatively, once a patient has been diagnosed as having $\alpha$ thalassaemia, especially women, it must be assumed that they will develop iron deficiency at the same rate as normal patients. Unfortunately, hypochromia will not be a guide.

We thank the nursing staff of the Corniche Hospital and Mrs Penny Stott and Mrs Val Rivers for their clerical help. We also thank Dr M Pippard for his helpful and critical comments.

\section{References}

${ }^{1}$ Pardini S, Oggiano L, Dore F, Madeddu S, Campus S, Longionitti M. IRCS Medical Sciences 1984;12:42-3.

${ }^{2}$ White JM, Richards R, Byrne M, Buchanan T, White YS, Jelenski G. J Clin Pathol 1985;38:810-7.

${ }^{3}$ Epremov GD. An evaluation of the methods used for quantitation of haemoglobin A2. Results from a survey of 10,063 cases. Haemoglobin 1977;2:197.

${ }^{4}$ England JM, Frazer PM. Differentiation of iron deficiency from thalassaemia trait by routine blood count. Lancet 1973;i:449-51.

${ }^{5}$ White JM, Byrne M, Richards R, Buchanan T. The frequency and expression of $\alpha$ and $\beta$ thalassaemia genes in North African, Arabian and Indian sub-continent populations. Am J Med Genet 1985 (in press).

Requests for reprints to: Professor JM White, El Seif/AMG Joint Venture, PO Box 25639, Riyadh 11466, Kingdom of Saudi Arabia. 